\title{
A simplified formula for determination of relative pressure in the precision forging of spur gears
}

\author{
Omer Eyercioglu* and Necip F. Y1lmaz \\ Mechanical Engineering Department, Gaziantep University, Gaziantep, 27310, Turkey. \\ *Corresponding Author: eyercioglu@gantep.edu.tr
}

Submitted: 29/03/2018

Revised: $\quad 10 / 11 / 2020$

Accepted: 23/11/2020

\begin{abstract}
In this study, the relative forging pressures of spur gears were evaluated. The precision forging of spur gears was analyzed by using the upper bound method considering corner filling and bulging effect. Numerical and experimental studies were performed to investigate the effects of various parameters, such as the number of teeth, modules, facewidth, bore diameter, and friction factor on the relative forging pressure of spur gears. The results were compared with the previous studies and a simplified formula was suggested to predict the relative pressure of precision forging of spur gears. The predicted relative forging pressures obtained by the suggested formula are shown much closer to the experimental results for the complete filling of the die cavity.
\end{abstract}

Keywords: Precision Forging; Spur Gear; Relative Pressure; Upper Bound; Forging Load.

\section{Nomenclature}

B bulging parameter

$\mathrm{D}_{\mathrm{i}} \quad$ bore diameter

f facewidth

$\mathrm{H}$ workpiece height

rn friction factor

M module

$\mathrm{N}$ number of teeth

$\mathrm{P}_{\mathrm{av}} \quad$ average forging pressure

$\alpha, \beta, \theta$ angles, (see Figure 1)

$\dot{\bar{\varepsilon}} \quad$ effective strain rate

$\dot{\mathrm{E}}_{\mathrm{p}, \mathrm{i}} \quad$ energy dissipation rate due to deformation in zone $\mathrm{i}$

$\dot{\mathrm{E}}_{\mathrm{S}} \quad$ energy dissipation rate due to velocity discontinuity

$\dot{\mathrm{E}}_{\mathrm{f}} \quad$ energy dissipation rate due to friction

$\bar{\sigma} \quad$ flow stress

$\dot{\mathrm{E}}_{\mathrm{r}} \quad$ total energy dissipation rate 


\section{INTRODUCTION}

Precision forging is especially attractive in the case of parts with complex surfaces that are difficult or costly to machine. The advantages of precision forging become obvious in high productivity. Not surprisingly, many precision forging applications involve gears and similar types of parts. Due to the improved mechanical properties of the forged gear in terms of strength (Kelley et al., 1974, Eyercioglu et al., 1997, Benedict, 1984) and durability (Townsand et al., 1976, Lehnhoff et al., 1983, Eyercioglu, 1995) with considerable savings in material utilization and manufacturing time (Eyercioglu et al., 1996) compared with traditional gear cutting methods, the production of gears by the precision forging has seen an increase in recent years. Although the production applications are usually for bevel gears in the early years of development strength (Skrocki, 1976, Sabroff et al., 1982, Benedict, 1989), spur and helical gears are now being formed (Y1lmaz et al., 2009, Eyercioglu et al., 2009, Y1lmaz et al., 2008, Y1lmaz et al., 2003), and further research is underway. Rectangular profile section of spur gears compared to the conical section of bevel gears makes them more difficult to form due to lack of natural draft (as exists for bevel gears) and perpendicular material flow requirement relative to punch movement during forging. Die design is probably the most important factor affecting the success of precision forging. The dimensional accuracy of the forged spur gears is dependent on the complete filling of the die cavity, and it can be achieved at high loads. Prediction of load requirement (i.e., corresponding relative pressure) for the precision forging of spur gears is an important aspect as in the case of any other forming processes.

There have been many attempts on the analysis of precision spur gear forging. They are mainly upper bound analyses and FEM. Slab method and slip-line field analyses are also carried out. Abdul and Dean (1986) studied the clamping type spur gear forging by using upper bound analysis considering the tooth profile was parallel to the centerline of the tooth. Grover and Juneja (1984) have analyzed the closed die spur gear forging assuming the tooth profile as a trapezoid. Chitkara and Bhutta (1999) modeled the deformation of gear-like parts using the upper bound method assuming the tooth profile as a straight line. Choi et al. $(1988,2000)$ presented mathematical models based on the upper bound method by assuming the tooth profile as a tapered line and an involute curve. However, most of them do not consider the corner filling stage and bulging effect during deformation. Sadeghi $(1989,2003)$ has been presented a model based on the upper bound method for the precision forging of spur and helical gears by using the trapezoidal tooth shape and the effect of bulging. Rasaee et al. (2013) proposed a mathematical model to investigate the forging of solid and hollow spur gears by using the upper bound method. They have used the involute curve for gear tooth and included the bulging effect. Irani et al. (2014) were used tapered tooth models in their upper bound analyses and compared the results with the experimental study.

With the increase in computing technology and the power of commercially available software packages in recent years, the simulations based on the finite element method have been used by many researchers to examine the influence of different metal flow designs and load requirements. Cai et al. (2004) carried out finite element simulations of netshape gear forging and discussed the effects of friction on the forging loads and mode of metal flow. Zadshakouyan et al. (2009) investigated the effects of gear parameters on the forging load and material flow by using DEFORM ${ }^{\mathrm{TM}} 3 \mathrm{D}$. Yang et al. (2014) were studied the reduction of forging load by using two-step forging in their FE simulations. Zuo et al. (2015) was studied the influences of relief cavity designs on corner filling, forming load, stresses encountered on the workpiece and die components, and material utilization by using FEM.

To predict the relative forging pressures by using the upper bound models (in the case of analytical studies); numerical integrations of the equations are required. In the case of FEM, the selection of boundary conditions and types of elements largely changes the results. Therefore, some amount of expertise is necessary to carry out the calculations. To overcome these difficulties, Tomov and Gagov (1999) suggested simplified mean pressure equations using the slab method, slip-line field analysis, and upper bound approach. These equations are valid for solid spur gears (bore diameter is zero). The results from the use of these equations are in close agreement with the experimental results obtained for the second stage of deformation (filling the tooth cavity mainly in the radial direction), but not enough to predict the pressure required for complete filling of the die cavity. 
The aim of this study is to evaluate the relative forging pressure of spur gears. For this purpose, an upper bound analysis of precision spur gear forging was done considering corner filling and bulging effect as suggested by Sadeghi (1989). Numerical and experimental studies were performed to investigate the effects of various parameters, such as the number of teeth, modules, facewidth, bore diameter, and friction factor on the relative forging pressure of spur gears. The results were compared with the previous studies, and a simplified formula was suggested to predict the relative pressure of precision forging of spur gears.

\section{UPPER BOUND ANALYSIS}

Upper bound analyses of spur gears have been presented previously (Sadeghi, 2003, Chitkara et al., 1999, Zadshakouyan et al., 2009, Rasaee, et al., 2013, Irani et al., 2014). In these studies, different kinematically admissible velocity fields that satisfy the boundary conditions (incompressibility, continuity, and velocity) have been chosen. Based on these velocity fields, deformation, shear (in the case of velocity discontinuities), and friction energy dissipation rates are calculated to determine the total forging energy and consequently the forging load. In most of the studies, using the symmetry of the gear tooth, half of the teeth is considered as shown in Figure 1. This segment is subdivided into different deformation zones. To simplify the model, a tapered straight line is assumed instead of the involute tooth profile (Sadeghi, 2003, Chitkara et al., 1999). In those studies, a half gear segment is basically divided into three zones of deformation. Choi and Choi (2000) proposed a six-zone deformation model with an involute profile.

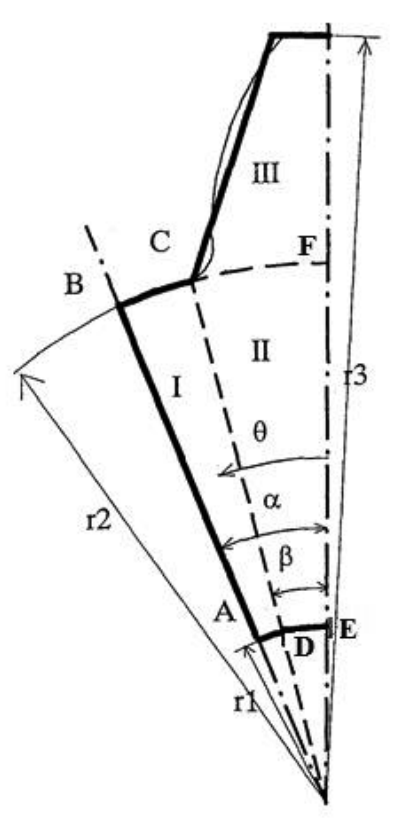

(a)

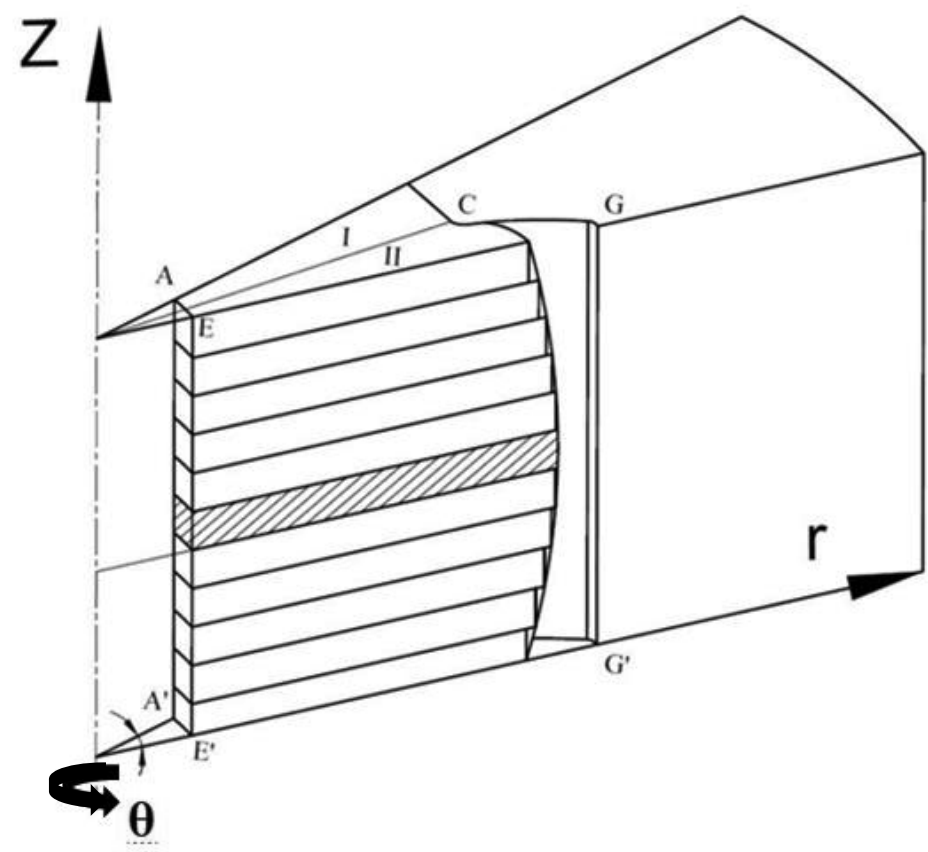

(b)

Figure 1. Deformation zones of a half tooth a) 2D and b) 3D models.

The previous studies that used the deformation model given in Figure 1, assume that material cannot cross or shear along the symmetry plane throughout the forging process. Hence, as the punch descends, the material in Zone 1 is restrained from flowing radially due to the constraint dictated by the mandrel and the die wall. The former defines part of the bore (AE), and the latter forms the root $(\mathrm{BC})$ of the gear to be forged. Therefore, material flows in a circumferential direction and enters Zone 2 . This material along with the radially displaced material by the punch's downward movement in Zone 2 flows into Zone 3 to form the tooth. 
As depicted in Figure 1.b, the deformation in Zone 3 is not uniform, and the material bulges due to the restraints at the contact surfaces. This mode of deformation in Zone 3 continues until the bulged free surface in the tooth cavity reaches the tooth tip of the die wall. After this stage, the unfilled corners start to fill, and the complete tooth is formed. The velocity fields considering the effect of bulging and corner filling are given in Table 1.

Table 1. The kinematically admissible velocity fields considering the effect of bulging and corner filling (Sadeghi, 1989).

\begin{tabular}{|c|c|c|}
\hline Zone 1 & $\begin{array}{l}\mathrm{U}_{\mathrm{r}}=0 \\
\mathrm{U}_{\Theta}=-\frac{\mathrm{r}(\alpha-\theta)}{\mathrm{H}} \\
\mathrm{U}_{\mathrm{z}}=-\frac{\mathrm{z}}{\mathrm{H}}\end{array}$ & $\begin{array}{l}(1) \\
(2) \\
(3)\end{array}$ \\
\hline Zone 2 & $\begin{array}{l}\mathrm{U}_{\mathrm{r}}=\frac{\mathrm{r}}{2 \mathrm{H}}\left[\frac{\pi(\alpha-\beta)}{2 \beta} \cos \left(\frac{\pi \Theta}{2 \beta}\right)+1\right. \\
\mathrm{U}_{\Theta}=-\frac{\mathrm{r}(\alpha-\beta)}{\mathrm{H}} \sin \left(\frac{\pi \Theta}{2 \beta}\right) \\
\mathrm{U}_{\mathrm{z}}=-\frac{\mathrm{z}}{\mathrm{H}}\end{array}$ & $\begin{array}{l}\text { (4) } \\
\text { (5) } \\
\text { (6) }\end{array}$ \\
\hline Zone 3 & $\begin{array}{l}U_{r}=A\left(1-B z^{2}\right) r+\frac{C}{r} \\
U_{\theta}=0 \\
U_{z}=-2 A\left(1-B \frac{z^{2}}{3}\right) z \\
\text { where } \\
A=\frac{1}{2 H\left(1-B \frac{H^{2}}{12}\right)} \\
C=\left[U_{m}-A r_{2}\left(1-B z^{2}\right)\right] r_{2} \\
U_{m}=\frac{r_{2}}{2 H}\left[\frac{\pi(\alpha-\beta)}{2 \beta}+\frac{1}{\cos \beta}+1\right] \\
B \text { is the bulge parameter which is } \\
\text { minimization of the total energy diss }\end{array}$ & $\begin{array}{l}(7) \\
(8) \\
(9)\end{array}$ \\
\hline
\end{tabular}

The total energy dissipation can be found in Table 1; 
i. The energy dissipation rate $\left(\dot{\mathrm{E}}_{\mathrm{p}}\right)$ due to deformation

$\dot{\mathrm{E}}_{\mathrm{p}, \mathrm{i}}=\int_{\mathrm{V}} \dot{\sigma \varepsilon} \mathrm{dV}$

where, $\mathrm{i}$ is zone number.

ii. The shear energy dissipation $\left(\dot{\mathrm{E}}_{\mathrm{S}}\right)$ at the surface of velocity discontinuity

$\dot{\mathrm{E}}_{\mathrm{S}}=\int_{\mathrm{S}} \frac{\bar{\sigma}}{\sqrt{3}}|\Delta \mathrm{V}| \mathrm{dS}$

where, $\mathrm{S}$ is the velocity discontinuity surface.

iii. The energy dissipation rate $\left(\dot{\mathrm{E}}_{\mathrm{f}}\right)$ due to friction

$\dot{\mathrm{E}}_{\mathrm{f}}=\int_{\mathrm{A}_{\mathrm{f}}} \frac{\mathrm{m} \bar{\sigma}}{\sqrt{3}}|\Delta \mathrm{V}| \mathrm{dA}$

where, $A_{\mathrm{f}}$ is the frictional interface.

The details of the plastic, shear, and frictional energy dissipation rate expressions are not given here because of the volume of the paper. Therefore, the relative punch pressure is calculated by:

$$
\frac{\mathrm{P}_{\mathrm{av}}}{\bar{\sigma}}=\frac{\dot{\mathrm{E}}_{\mathrm{T}}}{\overline{\bar{\sigma} A v_{0}}}
$$

where, $\mathrm{A}, \mathrm{v}_{0}$ and $\dot{\mathrm{E}}_{\mathrm{T}}$ are punch/workpiece contact area, punch velocity, and total energy dissipation rate, respectively.

$$
\dot{\mathrm{E}}_{\mathrm{T}}=\dot{\mathrm{E}}_{\mathrm{P}}+\dot{\mathrm{E}}_{\mathrm{S}}+\dot{\mathrm{E}}_{\mathrm{f}}
$$

\section{EXPERIMENTAL STUDIES}

In this section, spur gear forging experiments carried out by the authors are presented. The results of some available previous experimental studies are also given for comparison.

Gear Specification: A 24-tooth $3 \mathrm{~mm}$ module spur gear with an addendum equal to module and dedendum equal to 1.25 times module was selected. $0.1 \mathrm{~mm}$ of material stock was left on the tooth profile above the base diameter as a finishing allowance.

Forging Machine and Forging Die: The forging machine was a 10 MN (1000 Ton) capacity FM68 type Massey Eccentric Press. A duplex cylinder assembly with an AISI H13 die insert material and a B.S. 817M40 (En 24) shrink ring was used. The toolset comprised essentially a container, gear-shaped punch and ejector, and a mandrel. The forging press, the general assembly of the die set, and the die components are given in Figure 2.

Material: B.S. 817M40 (En 24) was selected as a frequently used gear material. B.S. 817M40 is suitable for heat treatments to obtain various tensile strengths, ductility, and shock and wear resistance. 

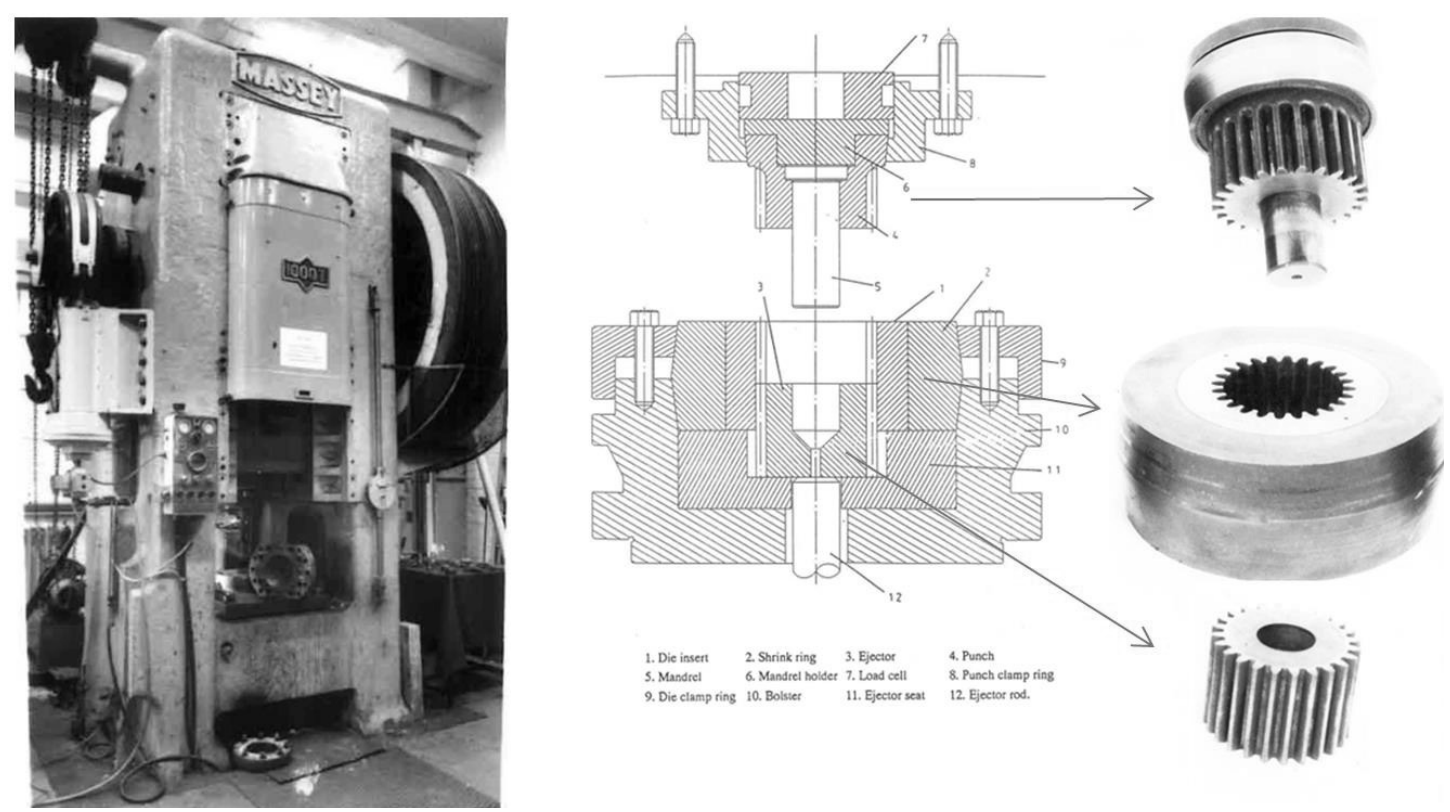

Figure 2. The experimental set up a) The forging press, b) the general assembly of the die set, and c) the die components.

Preform Geometry: To ease die filling, a hollow cylindrical preform was used. The inner diameter was selected to fit the mandrel and the outside diameter slightly smaller than the root diameter of the gear teeth, as suggested by Eyercioglu et al. (1997). The clearance, between the outside diameter of the preform and the root diameter of the gear, was carefully selected in order to compensate for the thermal expansion of the preform when heated and to enable it to be easily placed into the die cavity. The height of the preform is dependent on the facewidth of the gear to be forged. The preforms were cut from bar stock, then drilled, and turned to remove scale and decarburized material. At this stage, the preforms were checked for correct height and diameter to ensure that they were of the correct volume for the forging operation.

Preform Heating and Lubricants: The preforms were heated in an electric muffle furnace to a temperature of about $1225^{\circ} \mathrm{C}$. The heating time for each preform was kept as short as possible in order to minimize preforging scale formation and decarburization. The heating times were selected as being just adequate to bring all points of the preform to the required temperature. $\mathrm{MoS}_{2}$ was used as a lubricant, and care was taken to ensure that all the working surfaces were completely and evenly lubricated.

Forging Load and Punch Displacement Measurements: Forging loads were measured using a strain-gauged cylindrical load cell placed on the punch assembly. The load cell was calibrated using a hydraulic press. It was connected to a bridge amplifier, and the output from the bridge fed into an oscilloscope. Punch displacement, after the punch had touched the perform surface, was measured using an inductive displacement transducer. During forging, punch displacement was displayed against forging load on the oscilloscope.

\section{RESULTS AND DISCUSSION EXPERIMENTAL RESULTS}

Forging Load and Die Filling: Figure 3 shows the load versus displacement curve for the precision forged spur gear. The seven stages of the incremental forging tests are shown on the curve, and corresponding fillings are explained in Figure 4. Three consecutive stages can be defined during deformation: 
i) Free upsetting until reaching root diameter, Point 1 corresponds to this stage.

ii) Filling the tooth cavity mainly in the radial direction, up to Point 4.

iii) Complete filling of the tooth corners, up to Point 7.

As seen from Figure 4, the top corners of the gear are filled earlier than the bottom. This is due to the use of a punch, which enters the stationary cavity. The workpiece contacts to sidewalls of the die before the corners, therefore, frictional resistance increases and flow strength is also increasing due to cooling. The combination of increased friction and deformation load causes corner filling to be more difficult.

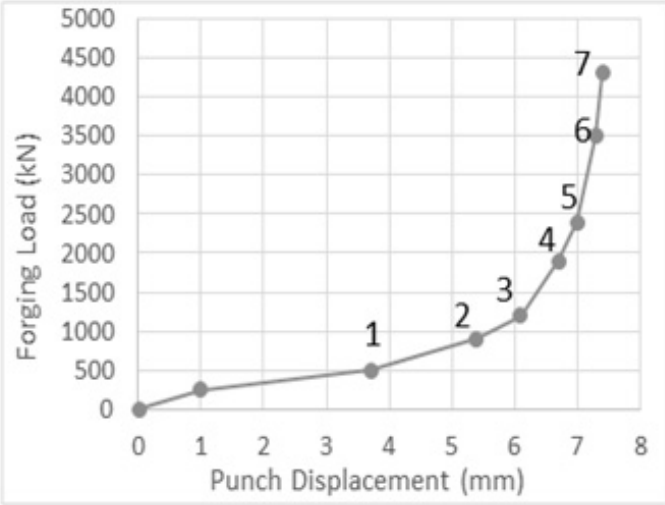

(a)

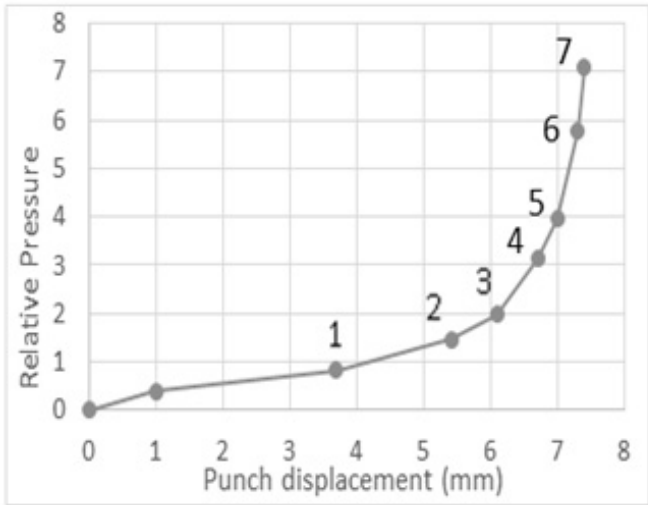

(b)

Figure 3. The a) punch load and b) relative pressure versus displacement curve for the precision spur gear forging.

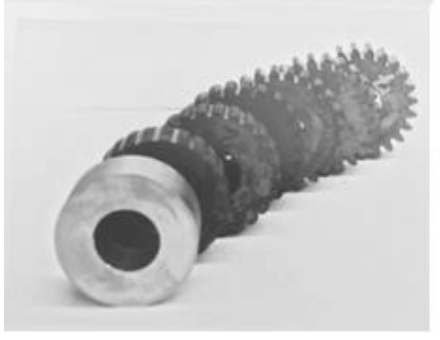

(a)

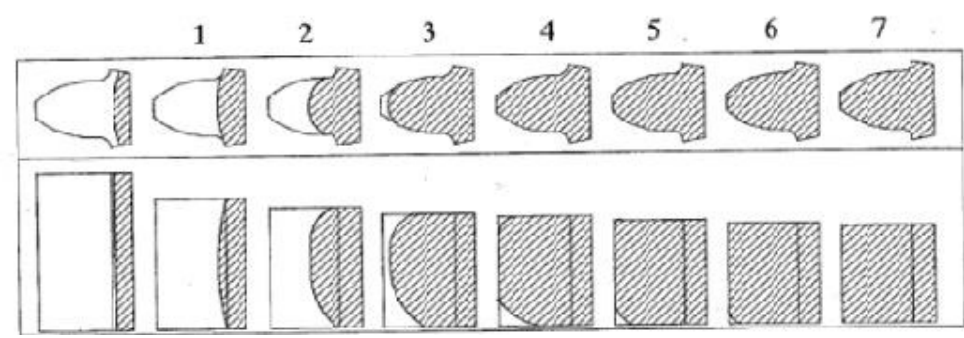

(b)

Figure 4. The corresponding die filling stages of the incremental precision gear forging a) forged gears and b) material flow.

\section{THE UPPER BOUND SOLUTIONS}

The equations of the upper bound analysis given in Section 2 are solved numerically using Mathematica (2017) [36], and results are given in Figures 5-8. In Figure 5, the relative forging pressure versus the number of teeth is plotted for different friction factors $(0 \leq \mathrm{m} \leq 1)$. The results are for a $3 \mathrm{~mm}$ module, $18 \mathrm{~mm}$ facewidth, and $20^{\circ}$ pressure angle solid (bore diameter $=0$ ) spur gears. The relative pressure is increasing linearly with the increasing number of teeth because the number of velocity discontinuity surfaces and frictional surfaces is increasing with teeth number. For nonfriction conditions $(\mathrm{m}=0)$, the effect of velocity discontinuity is obvious.

In Figure 6, relative forging pressure against gear-module is shown for friction factors changing from 0 to 1. The results are for a constant number of teeth $24,18 \mathrm{~mm}$ facewidth, and $20^{\circ}$ pressure angle solid (bore diameter $=0$ ) 
spur gears. The results show that the relative pressure changes very small amounts with an increase in gear module from the first stage to the corner filling stage of the deformation. During the corner filling stage, the relative pressure increases remarkably as the gear module increases. This is because the size of the frictional area (cross-sectional and lateral surface area) increases with an increase in the module. For the nonfriction condition $(\mathrm{m}=0)$, there is no change in relative pressure with the module.

The variation of relative pressure with facewidth is shown in Figure 7. The results are for a $3 \mathrm{~mm}$ module, 24 teeth, $20^{\circ}$ pressure angle, and bore diameter of $30 \mathrm{~mm}$ spur gears. Up to corner filling stage, effect of facewidth on relative pressure is very small. During corner filling, relative pressure slightly decreases with increasing facewidth. The reason is that; the surface area to volume ratio is decreasing, while the frictional surface area is increasing with facewidth.

Figure 8 shows the variation of relative pressure with bore diameter. The results are for a $3 \mathrm{~mm}$ module, 24 teeth, $18 \mathrm{~mm}$ facewidth, and $20^{\circ}$ pressure angle spur gears. From the figure, it is seen that relative pressure is increasing with an increase in bore diameter. This is due to the fact that the frictional surface between the bore surface and the tooling (mandrel) increases as the bore diameter increases.

From Figures 5-8, it is evident that the relative pressure increases with an increase in friction factor.

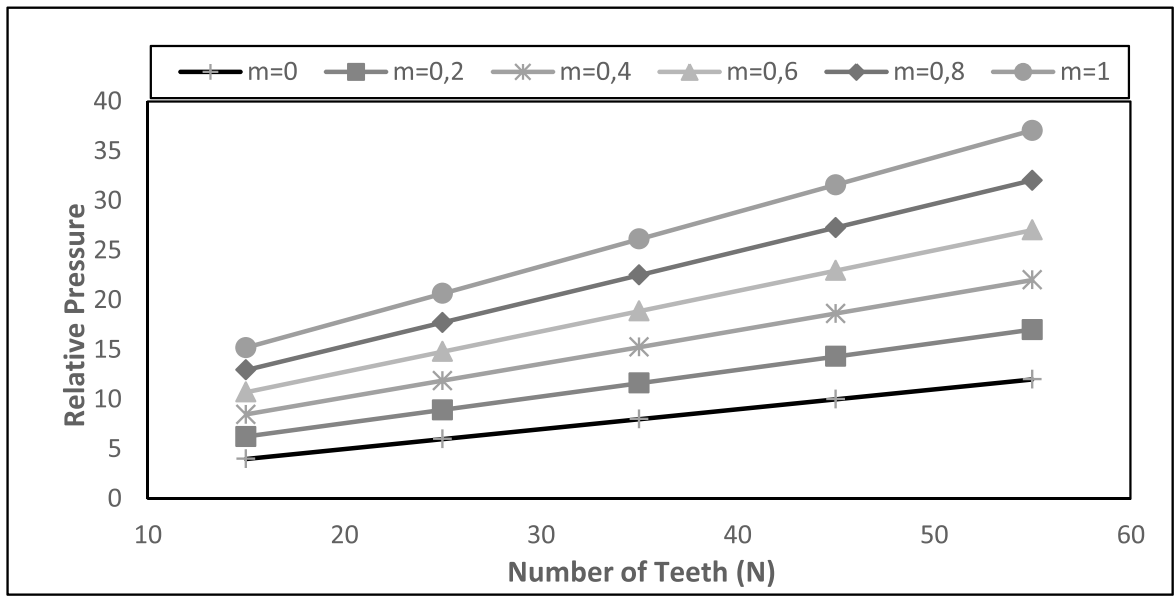

Figure 5. The relative forging pressure versus number of teeth $(\mathrm{M}=3, \mathrm{f}=18, \mathrm{Di}=0)$.

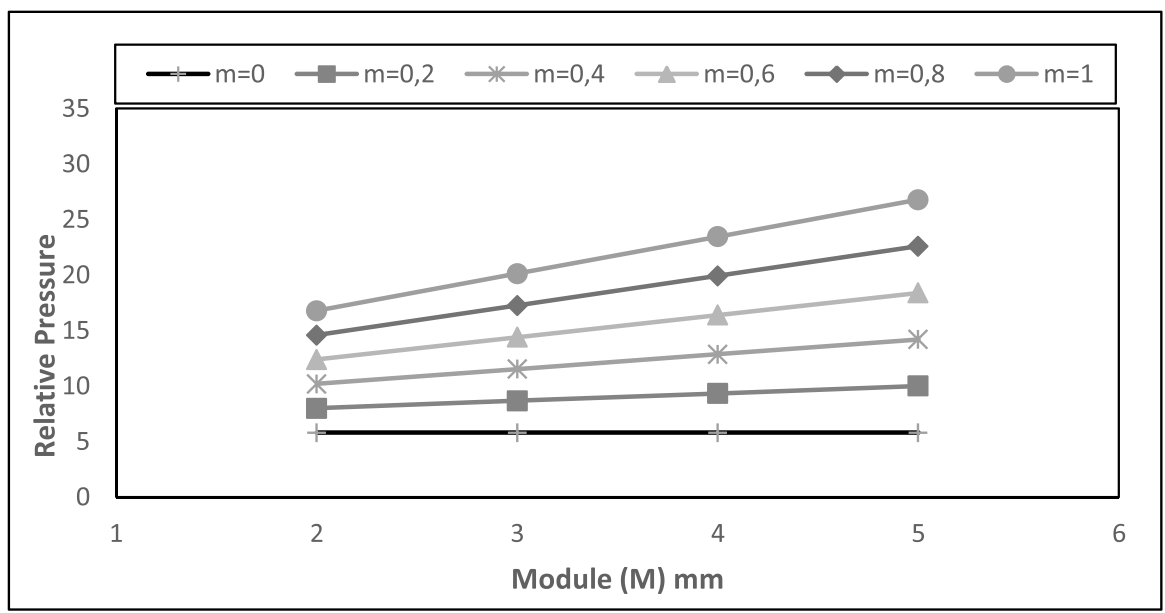

Figure 6. The change in relative forging pressure with respect to gear module $(\mathrm{N}=24, \mathrm{f}=18, \mathrm{Di}=0)$. 


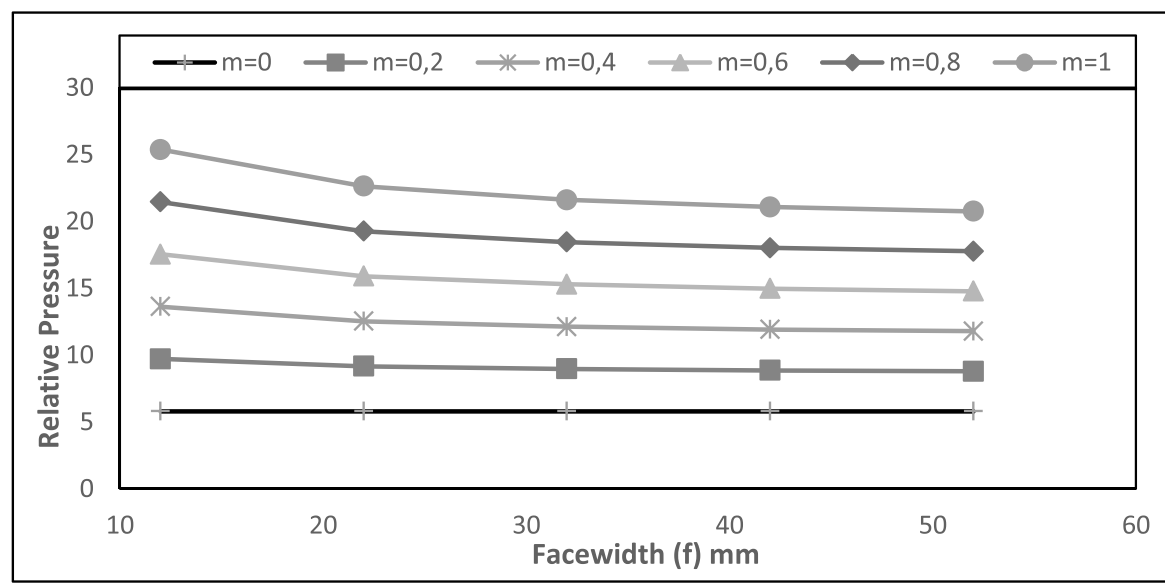

Figure 7. The variation of relative pressure with facewidth $(\mathrm{M}=3, \mathrm{~N}=24, \mathrm{Di}=30)$.

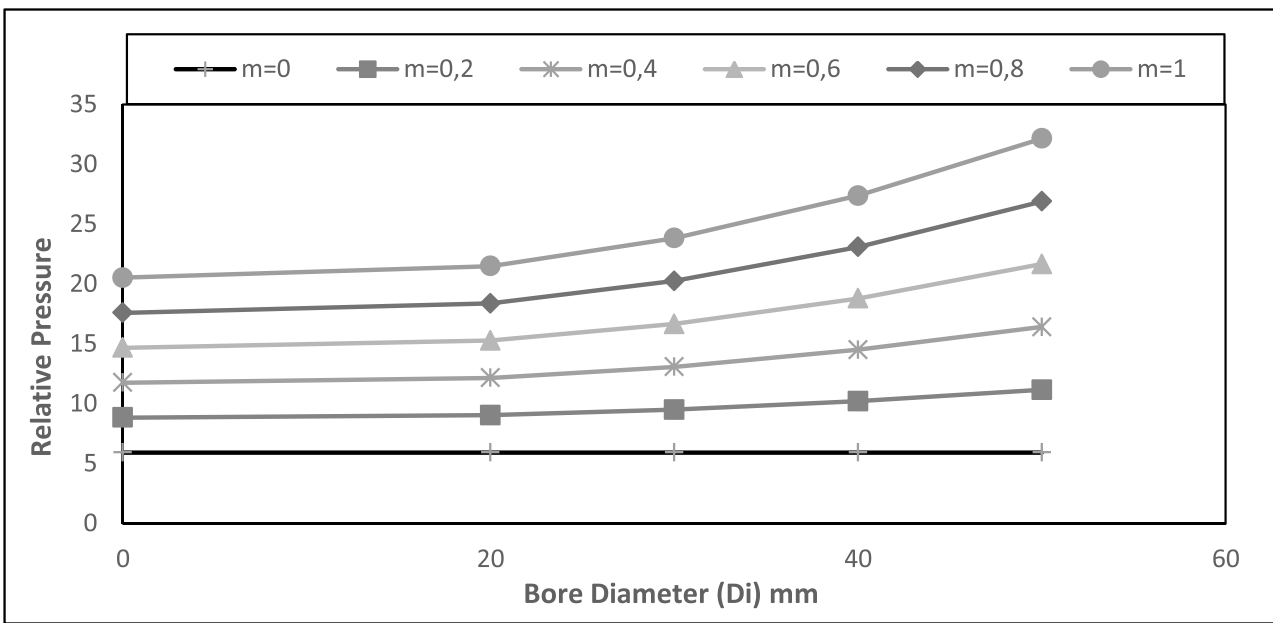

Figure 8. The variation of relative pressure with bore diameter $(\mathrm{M}=3, \mathrm{~N}=24, \mathrm{f}=18)$.

\section{A NEW SIMPLIFIED FORMULA FOR RELATIVE FORGING PRESSURE}

For the determination of the relative forging pressure, a simplified formula based on the upper bound solution is suggested as;

$$
\frac{\mathrm{P}_{\mathrm{av}}}{\bar{\sigma}}=1+0.2 \mathrm{~N}+\mathrm{m}\left[2 \mathrm{M}+0.18 \mathrm{~N}+\frac{\mathrm{MN}}{\mathrm{f}}+0.006\left(\mathrm{D}_{\mathrm{i}}{ }^{2}-12 \mathrm{D}_{\mathrm{i}}\right)\right]
$$

The presented formula given in equation 15 is well suited with the upper bound analysis results as shown in Figures 9-17. The formula is also tested for the experimental and theoretical results of various sizes of forged gears that are available in the literature. The gear specifications of the experimental studies are summarized in Table 2.

Figure 9 shows the theoretical and experimental results of the four cases summarized in Table 2 . The formula and the upper bound analysis are in good agreement. The experimental relative forging pressure results for all the cases are smaller than the results of the formula (i.e., upper bound solution). This is due to the nature of the upper bound analysis, which always predicts higher values, and safer for die design. The results of equations suggested by Tomov and Gagov (1999) based on the slab method and slip-line field analyses are much lower because their approach is valid for the second stage of deformation up to Point 4 in Figure 3. They do not consider the third stage of deformation (i.e., corner filling) and also bore diameter effect. 
Table 2. The gear specifications of some available previous experimental works.

\begin{tabular}{|c|c|c|c|c|c|}
\hline $\begin{array}{c}\text { Case } \\
\text { No }\end{array}$ & $\begin{array}{c}\text { The Previous } \\
\text { Study }\end{array}$ & $\begin{array}{c}\text { Module } \\
\mathrm{M}(\mathrm{mm})\end{array}$ & $\begin{array}{c}\text { Number of teeth } \\
\mathrm{N}\end{array}$ & $\begin{array}{c}\text { Facewidth } \\
\mathrm{f}(\mathrm{mm})\end{array}$ & $\begin{array}{c}\text { Bore diamete, } \\
\mathrm{D}_{\mathrm{i}}(\mathrm{mm})\end{array}$ \\
\hline 1 & Sadeghi (1989) & 5.08 & 13 & 25 & 0 \\
\hline 2 & Sadeghi (1989) & 5.08 & 13 & 25 & 0 \\
\hline 3 & Eyercioglu (2009) & 3.0 & 24 & 18 & 30 \\
\hline 4 & Tuncer (1985) & 2.5 & 24 & 15.9 & 36 \\
\hline 5 & Abdul (1986) & 2 & 22 & 15.6 & 0 \\
\hline 6 & Choi (2000) & 2 & 15 & 10 & 0 \\
\hline 7 & Choi (2000) & 2 & 15 & 10 & 10 \\
\hline 8 & Cai (2004) & 4,233 & 27 & 36 & 30 \\
\hline 9 & Yang (2014) & 3 & 18 & 15 & 0 \\
\hline 10 & Zuo (2015) & 2,117 & 31 & 17 & 20 \\
\hline
\end{tabular}

The comparison for variation of relative pressure with facewidth is given in Figure 10. The trends of all studies are similar except slip-line field analysis (Tomov et al., 1999). Neglecting the effect of pressure angle, the upper bound analysis done by Chitkara and Bhutta (1999) is also compared in that figure. Again, they said their results estimated by upper bound are lower than those observed experimentally towards the end of the deformation. They described filling of the die cavity is "fairly" satisfactory (gear teeth seem chamfered along the bottom edges) in their study. Complete filling of the die cavity increases relative forging pressure exponentially and due to that, the results of the suggested formula (Equation 15) are higher than Chitkara and Bhutta (1999).

In Figure 11, the comparison for variation of relative pressure with a friction factor is given. The experimental results for case 1 and 2 in Table 2, are just below the results of the formula but much higher than the results of equations suggested by Tomov and Gagov (1999). The formula gives similar results with the calculated values of the upper bound analysis up to friction factor $\mathrm{m}=0.6$. For higher values of friction factor, the upper bound analysis estimates lower values of relative pressures.

A similar comparison is done for Abdul and Dean's study (1986) and shown in Figure 12. The results are for a $2 \mathrm{~mm}$ module, 22 teeth, $15.6 \mathrm{~mm}$ facewidth, and $20^{\circ}$ pressure angle solid spur gears (bore diameter is zero). The results are closer to each other because their analysis is for the tooth filling stage. The difference is coming from the consideration of the bulging effect.

In Figure 13, the relative forging pressure with respect to the number of teeth is plotted for this and some previous studies (Grover et al., 1984, Chitkara et al., 1999, Tomov et al., 1999). The formula and the results of Grover and Juneja (1984) are close. Chitkara and Bhutta (1999) results are about half of the formula. The work done by Choi and Choi (1998) is also compared for $1.5 \mathrm{~mm}$ and $3 \mathrm{~mm}$ module gears in Figures 14.a and 14.b, respectively. The results are for $10 \mathrm{~mm}$ facewidth, the friction factor of 0.1 , bore diameter $30 \%$ of the root diameter, and $20^{\circ}$ pressure angle spur gears. For both values of the module, the relative pressures determined by Choi et al. (1998) are lower than the results of the formula. Because their results are not for complete filling of the die cavity. During their experiments, the punch movement stopped when the punch pressure reached a maximum value of $1800 \mathrm{MPa}$, because of the strength limitations of the die and punch. Because of that, they have some different fillings and lower results of relative pressures. 


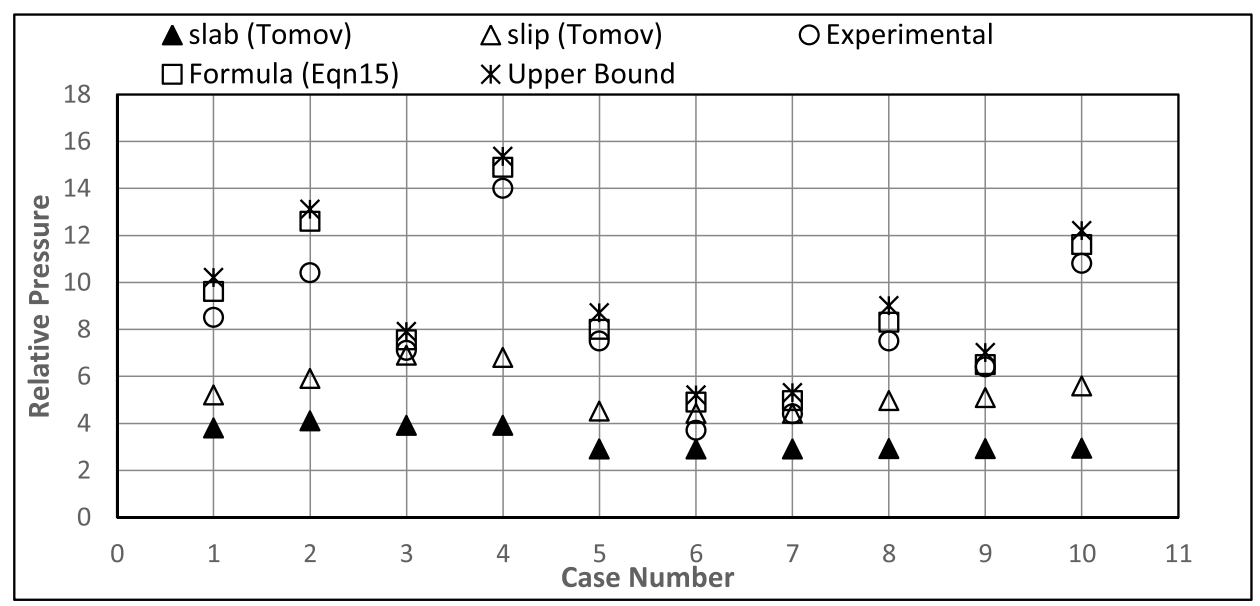

Figure 9. Relative pressure comparisons all cases given in Table 2.

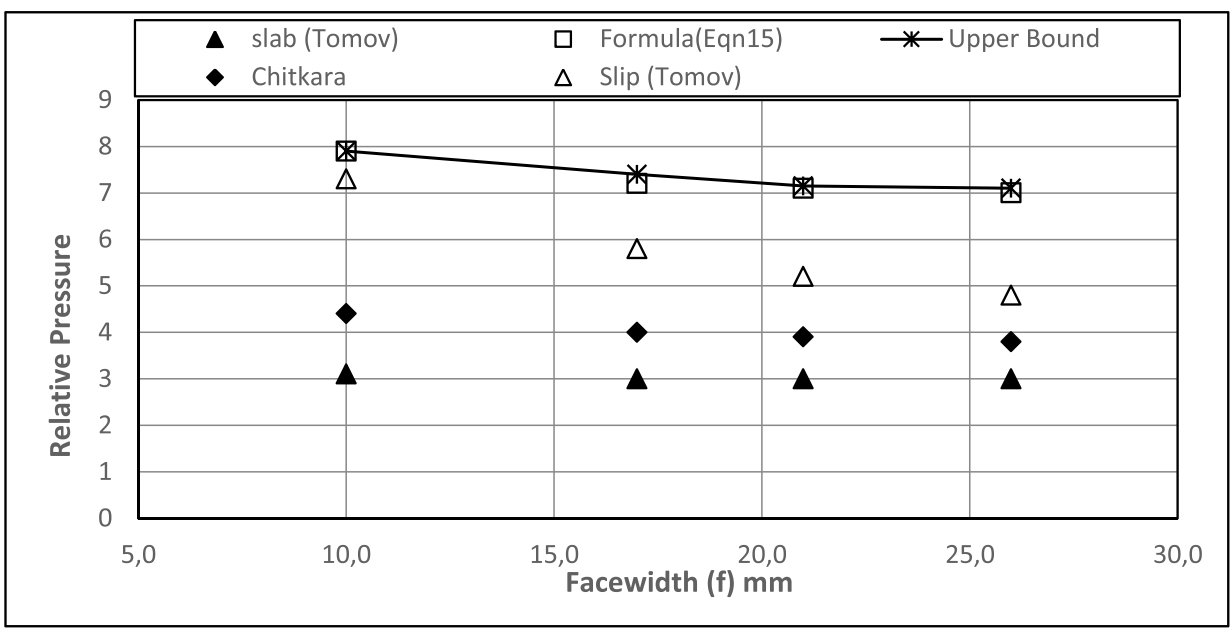

Figure 10. The comparison for variation of relative pressure with facewidth.

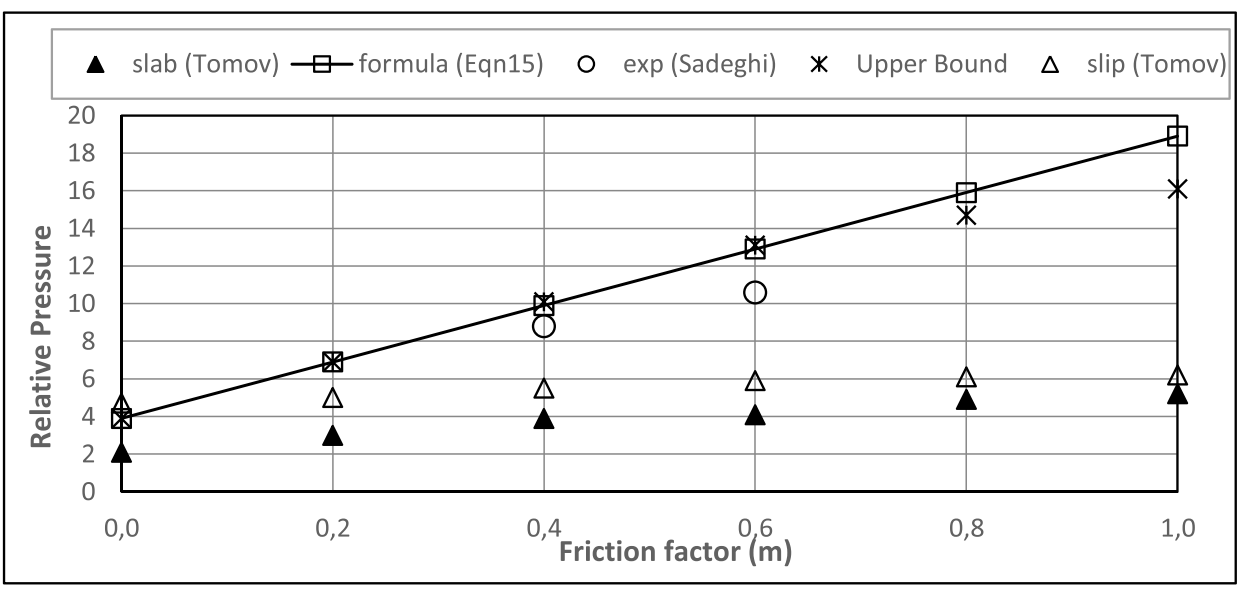

Figure 11. The comparison for variation of relative pressure with friction factor. 


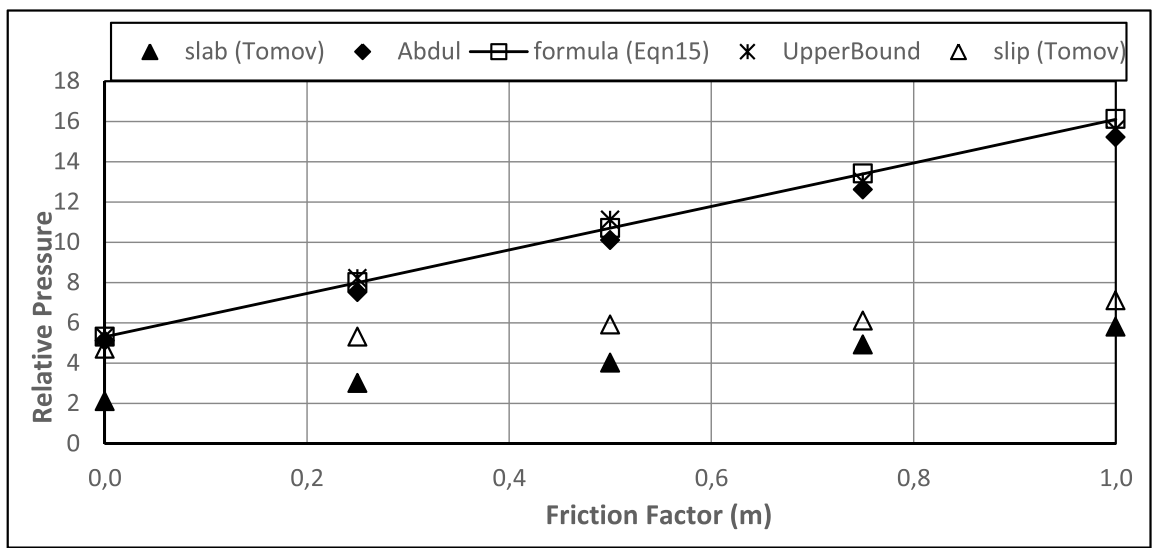

Figure 12. The comparison for variation of relative pressure with friction factor (for a $2 \mathrm{~mm}$ module, 22 teeth, 15.6 $\mathrm{mm}$ facewidth, and $20^{\circ}$ pressure angle solid spur gears).

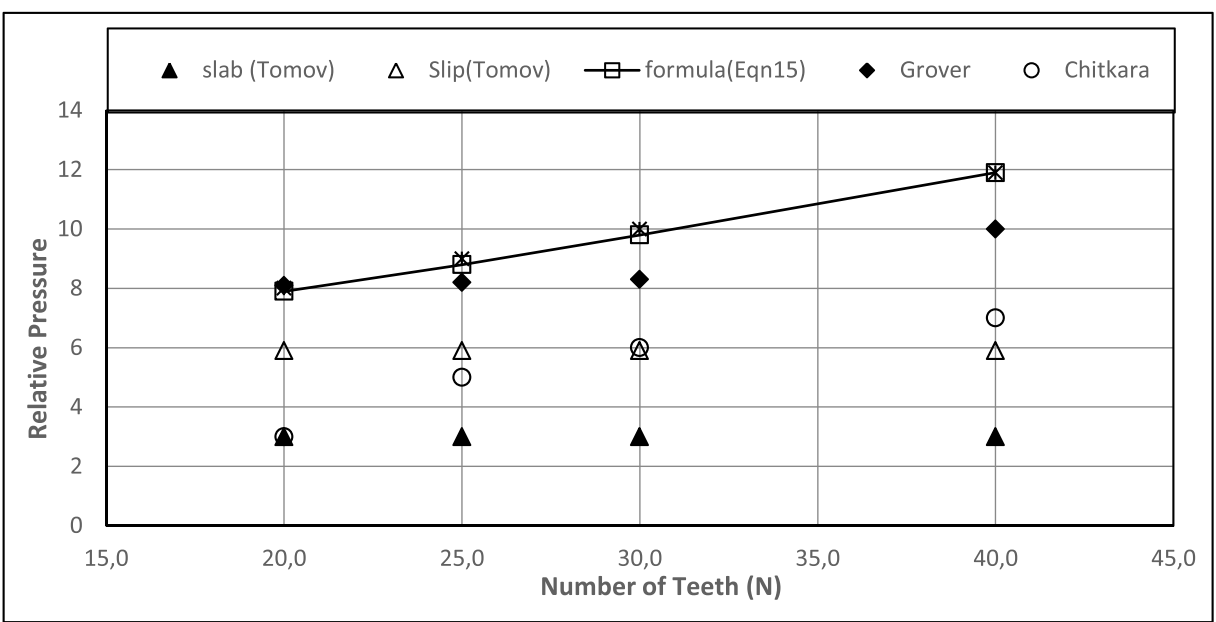

Figure 13. The variation of relative forging pressure with number of teeth.

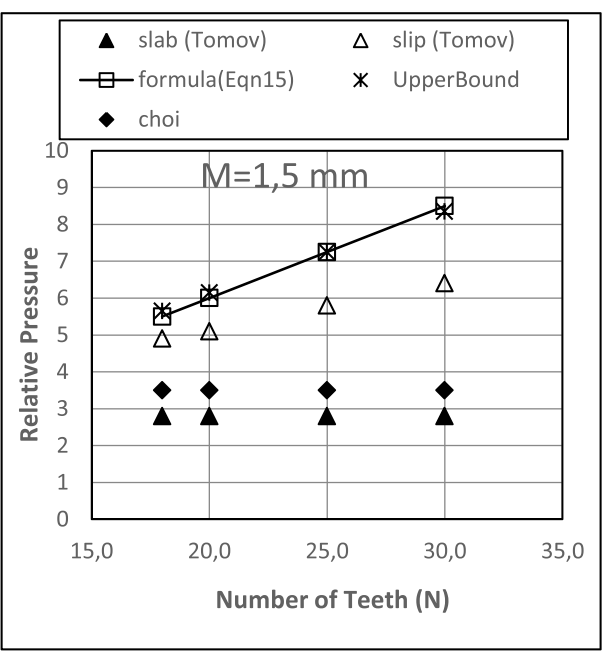

(a)

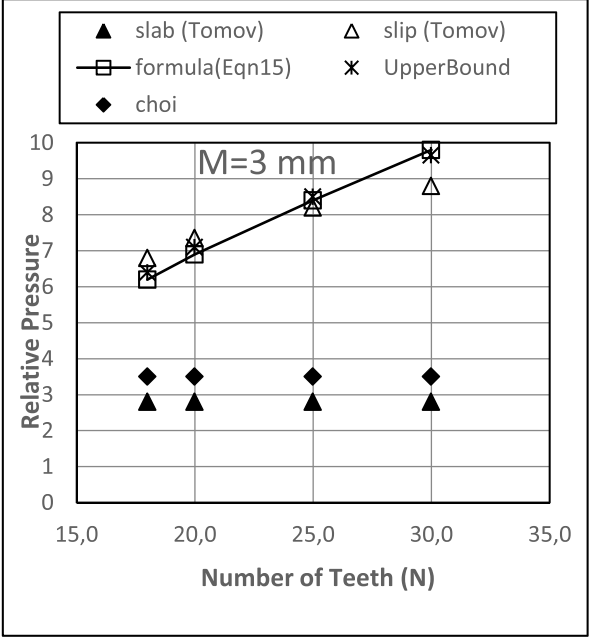

(b)

Figure 14. The variation of relative forging pressure with number of teeth a) $M=1.5 \mathrm{~mm}$ and b) $M=3 \mathrm{~mm}$. 


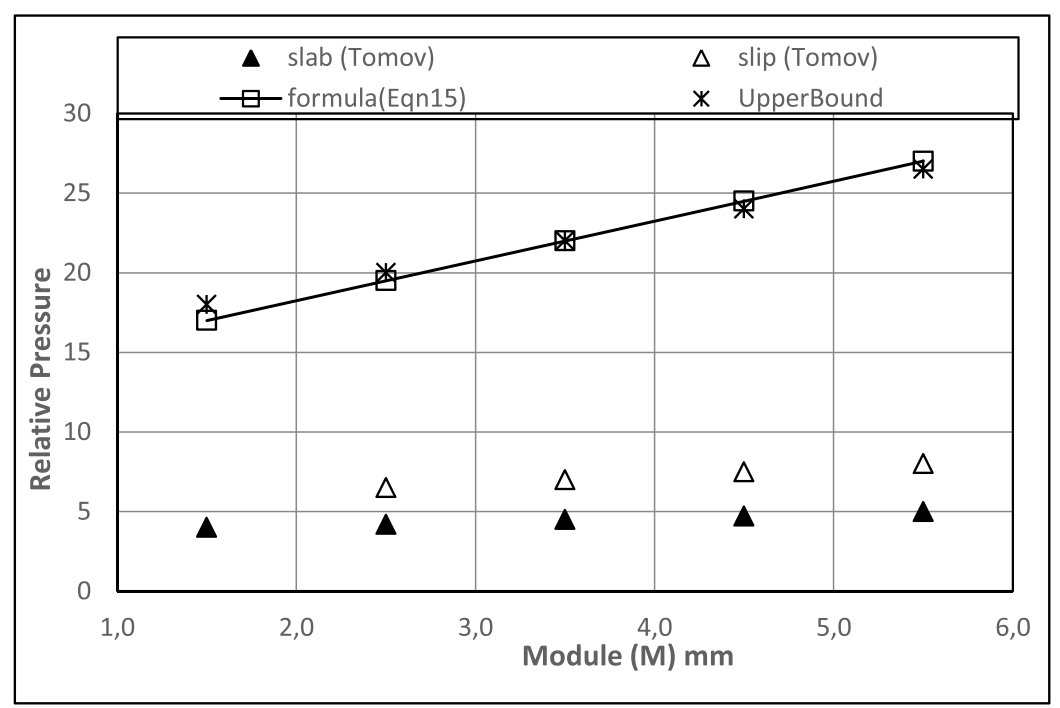

Figure 15. The variation of relative forging pressure with module.

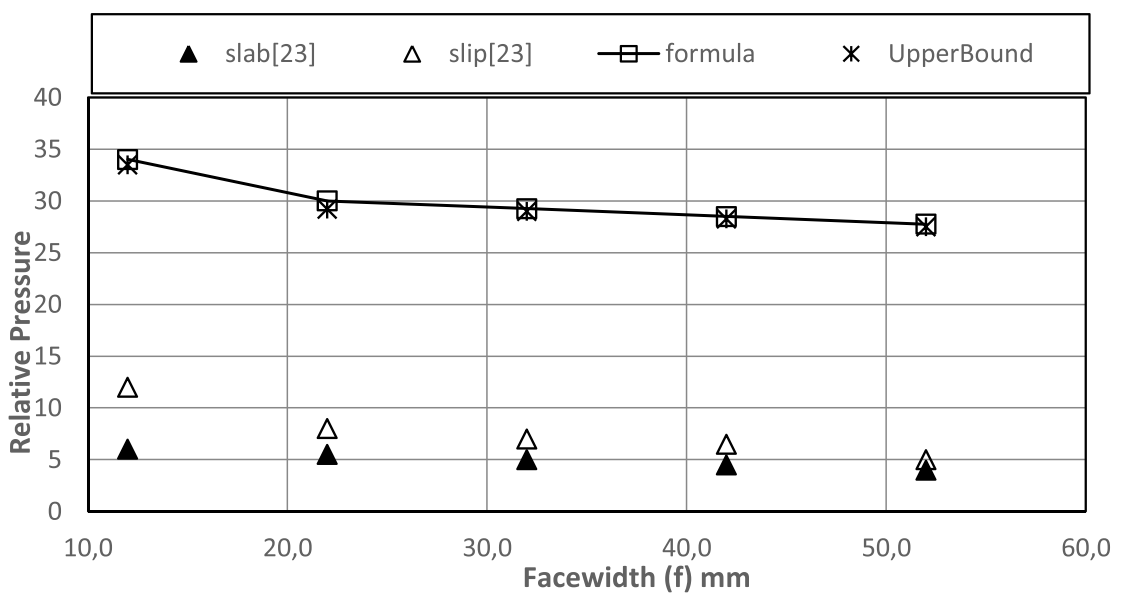

Figure 16. The variation of relative forging pressure with facewidth.

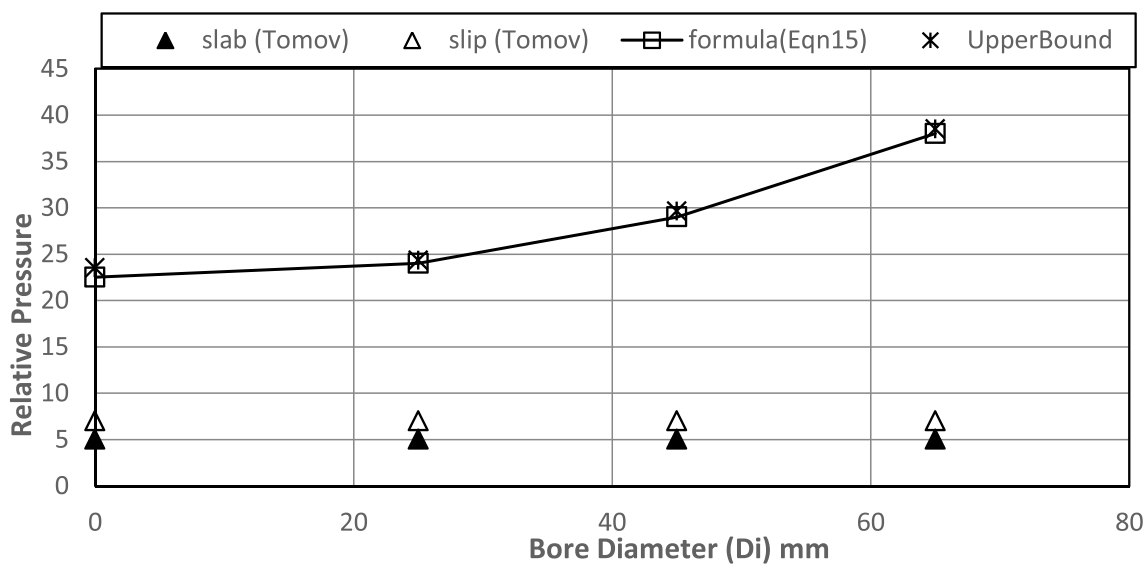

Figure 17. The variation of relative forging pressure with bore diameter. 


\section{CONCLUSIONS}

From the presented study carried out for precision forging of spur gears, the following conclusions can be made:

1. The relative forging pressure (i.e., forging load) is exponentially increasing at the third stage of deformation where corner filling of the teeth takes place. In most of the previous studies, the complete filling is not considered, so that, lower values of relative pressures are presented.

2. An upper bound analysis is carried out considering corner filling and bulging effect. Based on this analysis, a new simplified formula for prediction of relative forging pressure is suggested as a function of gear parameters (module, facewidth, number of teeth, and bore diameter).

3. The comparison of the results shows that the upper bound analysis and the formula presented in this study are slightly higher than the experimental ones. Also, the results are closer to the previous studies, which are considered corner filling. Both the experimental and the formula results are much higher than the previous result due to the bulging effect and corner filling.

\section{REFERENCES}

Abdul, N.A., Dean, T.A. 1986. An Analysis of The Forging of Spur Gear Forms, Int J Mach Tool Des Res, 26(2):113-123.

Benedict, D.K. 1984. Forged Straight Bevel Gears-An Overview, AGMA pp 84-1949.

Benedict, D.K. 1989. The CIM of Net Shape Forged Bevel Gears, Journal of Mater. Shaping Technol, 7(1): 7-11.

Cai, J., Dean, T.A., Hu, Z.M. 2004. Alternative Die Designs in Net-Shape Forging of Gears, J. Mater. Proc. Tech. 150(1): 48-55

Chitkara, N.R., Bhutta, M.A. 1999. Forging and Heading of Hollow Spur Gear Forms: An Analysis and Some Experiments, Int J Mech Sci, 41: 1159-1189

Choi, J., Cho, H.Y., Jo, C.Y. 2000. An Upper-Bound Analysis for the Forging of Spur Gears, J. Mater. Proc. Tech. 104: 67-73

Choi, J.C., Choi, Y. 1998. A Study on the Forging of External Spur Gears: Upper Bound Analyses and Experiments, Int J Mach Tool Des Res, 38:1193-1208

Eyercioglu O., Walton, D., Dean, T.A. 1997. Comparative Bending Fatigue Strength of Precision Forged Spur Gears, Proc. Instn. Mech Engrs IMechE, Part C, 211: 293-299. September

Eyercioglu, O. 1995. Developments and performance analyses of precision forged spur gears, PhD. Thesis, School of Man. And Mech. Eng., The University of Birmingham, England.

Eyercioglu, O., Dean, T.A., Walton, D. 1996. Precision Forging of Gears, $7^{\text {th }}$ Int. Mach. Des. and Prod Conf. Ankara, Turkey, 433-442.

Eyercioglu, O., Kutuk, M.A., Yilmaz, N.F. 2009. Shrink fit design for precision gear forging dies. journal of materials processing technology, 209(4): 2186-2194.

Grover, 0.P., Juneja, B.L. 1984. Analysis of Closed-die Forging of Gear Like Element, Adv Tech Plasticity, 888-893.

Irani, M., Najafabadi, R.A., Isfahani, T.D. 2014. A Study of Precision Forging of Steel Spur Gears: Upper Bound Model and Experiments, Int. J. of ISSI, v11, n1, 18-23.

Kelley, M., Danis, L. 1974. Precision Flow Forged Gears, Metals Eng. Quarterly, 20-22. November

Lehnhoff, T.F., Chen, H., Ardayfio, D.D. 1983. Surface Durability of Forged and Machined Steel Gears, ASME pp 83-DE-6, Mathematica, Wolfram Research, Inc. https://www.wolfram.com/mathematica

Rasaee, S., Haghighat, H., Zahedi, M. 2013. Modelling and Upper Bound Analysis of Involute Spur Gear Precision Forging, Int. Res. J. of Applied and Basic Sciences, 4(7): 1676-1682

Sabroff, A.M. 1982. Application of CAD/CAM Techniques to Close Tolerance Forging of Bevel Gears, Annals of the CRIP, 31(1): 141-153.

Sadeghi, M.H. 1989. Precision Forging Axisymmetric Shapes, Straight and Helical Spur Gears, PhD. Thesis, School of Man. And 
Mech. Eng., The University of Birmingham, England.

Sadeghi, M.H. 2003. Gear Forging: Mathematical Modeling and Experimental Validation, J. of Manuf. Science and Engineering, 125(4): 753-762.

Skrocki, R.R. 1976. Precision Forging of Spiral Bevel Gears, Metals Eng. Quarterly, February 58-64.

Tomov, B.I., Gagov, V.I. 1999. Modelling and Description of the Near-net Shape Forging of Cylindrical Spur Gears, J Mater Proc Tech, 92-93: 444-449

Townsand, D.P., Bamberger, E.N., Zaretsky, E.V. 1976. A life Study of Ausforged, Standard Forged and Standard Machined AlSI M-50 Spur gears, Transactions. of ASME, Journal of Lubrication Tech., 418-425, July.

Tuncer, M.C. 1985. Precision Forging Hollow Parts, PhD. Thesis, Department of Mechanical Engineering, The University of Birmingham, England.

Yang, C., Zhao, S., Zhang, J. 2014. Precision Forging of Spur Gear by Flow Control Forming Method, Australian j. of Mech. Eng. v12, n1, 101-109.

Yilmaz, N.F., Eyercioglu, O. 2003. Application of UBET in the Prediction of Forging Load for Axisymmetric Forging. International Journal of Advanced Manufacturing Systems, 6(1): 1-11.

Yilmaz, N.F., Eyercioglu, O. 2008. Knowledge based reverse engineering tool for near net shape axisymmetric forging die design. Mechanics, 73(5): 65-73.

Yilmaz, N.F., Eyercioglu, O. 2009. An integrated computer-aided decision support system for die stresses and dimensional accuracy of precision forging dies. The International Journal of Advanced Manufacturing Technology, 40(9-10): 875-886.

Zadshakouyan, M., Sobbouhi, E.A., Jafarzadeh, H. 2009. A Study on the Heading of Spur Gears: Numerical Analysis and Experiments, Int. J. of Mech. Aerospace, Industrial, Mechatronic Manuf. Eng. V3, n4, 380-384.

Zuo, B., Wang, B., Li, Z., Zheng, M., Zhu, X. 2015. Design of Relief-Cavity in Closed-Precision Forging of Gears, j. Cent. South Univ. 22, 1287-1297 DOI: 10.1007/s11771-015-2645-0 